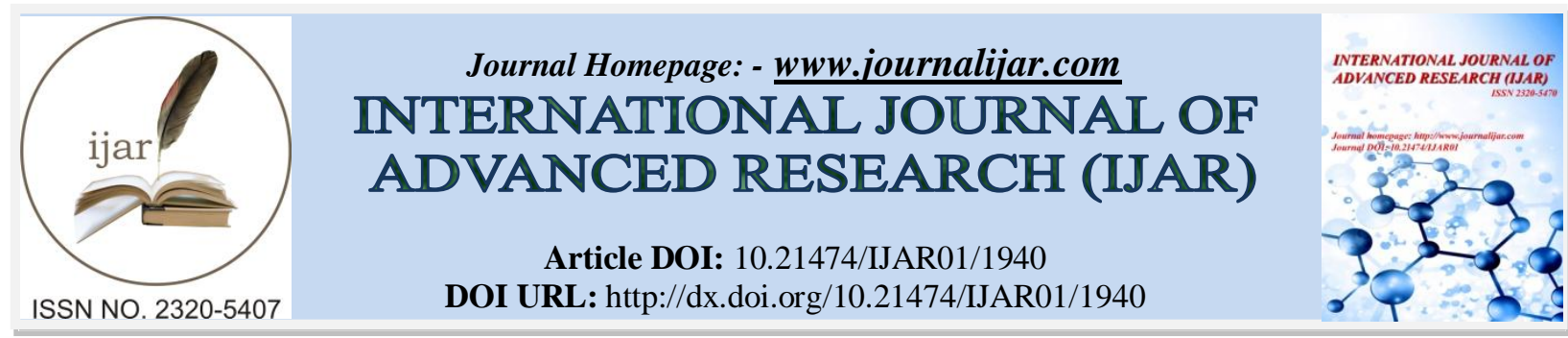

RESEARCH ARTICLE

ROLE OF SOCIAL MEDIA IN SOCIAL AUDIT.

Trilochan Chorasia.

Research Scholar in Management Punjab Technical University Jalandhar Punjab.

\section{Manuscript Info}

Manuscript History

Received: 22 August 2016

Final Accepted: 15 September 2016

Published: October 2016

\begin{abstract}
Social media and Social audit and assurance professionals are expected to customize this document to the environment in which they are performing an assurance process. This document is to be used as a review tool and starting point. It may be modified by the IT audit and assurance professional; it is not intended to be a checklist or questionnaire. It is assumed that the IT audit and assurance professional has the necessary subject matter expertise required to conduct the work and is supervised by a professional with the Certified Information Systems Auditor (CISA) designation and/or necessary subject matter expertise to adequately review the work performed.
\end{abstract}

Copy Right, IJAR, 2016,. All rights reserved.

\title{
What is social Media?
}

Social media are computer-mediated tools that allow people to create, share, or exchange information, career interests, ideas, and pictures/videos in virtual communities and networks. Social media is defined as "a group of Internet-based applications that build on the ideological and technological foundations of Web 2.0, and that allow the creation and exchange of user-generated content." Furthermore, social media depends on mobile and webbased technologies to create highly interactive platforms through which individuals and communities share, cocreate, discuss, and modify user-generated content. They introduce substantial and pervasive changes to communication between businesses, organizations, communities, and individuals. These changes are the focus of the emerging field of technoself studies. Social media differ from traditional or industrial media in many ways, including quality, reach, frequency, usability, immediacy, and permanence. Social media operates in a dialogic transmission system (many sources to many receivers). This is in contrast to traditional media that operates under a monologic transmission model (one source to many receivers).

"Social media has been broadly defined to refer to 'the many relatively inexpensive and widely accessible electronic tools that enable anyone to publish and access information, collaborate on a common effort, or build relationships."

There are many effects that stem from Internet usage. According to Nielsen, Internet users continue to spend more time with social media sites than any other type of site. At the same time, the total time spent on social media in the U.S. across PC and mobile devices increased by 99 percent to 121 billion minutes in July 2012 compared to 66 billion minutes in July 2011. For content contributors, the benefits of participating in social media have gone beyond simply social sharing to building reputation and bringing in career opportunities and monetary income, as discussed in Tang, Gu, and Whinston (2012) 


\section{Honeycomb framework of social media:-}

Identity:- This block represents the extent to which users reveal their identities in a social media setting. This can include disclosing information such as name, age, gender, profession, location, and also information that portrays users in certain ways.

Conversations:- This block represents the extent to which users communicate with other users in a social media setting. Many social media sites are designed primarily to facilitate conversations among individuals and groups. These conversations happen for all sorts of reasons. People tweet, blog, et cetera to meet new like-minded people, to find true love, to build their self-esteem, or to be on the cutting edge of new ideas or trending topics. Yet others see social media as a way of making their message heard and positively impacting humanitarian causes, environmental problems, economic issues, or political debates.

Sharing:- This block represents the extent to which users exchange, distribute, and receive content. The term 'social' often implies that exchanges between people are crucial. In many cases, however, sociality is about the objects that mediate these ties between people - the reasons why they meet online and associate with each other.

Presence:- This block represents the extent to which users can know if other users are accessible. It includes knowing where others are, in the virtual world and/or in the real world, and whether they are available.

Relationships:- This block represents the extent to which users can be related to other users. Two or more users have some form of association that leads them to converse, share objects of sociality, meet up, or simply just list each other as a friend or fan.

Reputation:- This block represents the extent to which users can identify the standing of others, including themselves, in a social media setting. Reputation can have different meanings on social media platforms. In most cases, reputation is a matter of trust, but because information technologies are not yet good at determining such highly qualitative criteria, social media sites rely on 'mechanical Turks': tools that automatically aggregate usergenerated information to determine trustworthiness. Reputation management is another aspect and use of social media.

Groups:- This block represents the extent to which users can form communities and sub communities. The more 'social' a network becomes, the bigger the group of friends, followers, and contacts.

\section{Social media Examples:-}

Facebook is a popular free social networking website that allows registered users to create profiles, upload photos and video, send messages and keep in touch with friends, family and colleagues. According to statistics from the Nielsen Group, Internet users within the United States spend more time on Facebook than any other website.

Twitter is a free microblogging service that allows registered members to broadcast short posts called tweets. Twitter members can broadcast tweets and follow other users' tweets by using multiple platforms and devices.

Google+ (pronounced Google plus) is Google's social networking project, designed to replicate the way people interact offline more closely than is the case in other social networking services. The project's slogan is "Real-life sharing rethought for the web."

Wikipedia is a free, open content online encyclopedia created through the collaborative effort of a community of users known as Wikipedians. Anyone registered on the site can create an article for publication; registration is not required to edit articles. Wikipedia was founded in January of 2001.

LinkedIn is a social networking site designed specifically for the business community. The goal of the site is to allow registered members to establish and document networks of people they know and trust professionally.

Reddit is a social news website and forum where stories are socially curated and promoted by site members. The site is composed of hundreds of sub- communities, known as "subreddits." Each subreddit has a specific topic such as technology, politics or music. Reddit site members, also known as, "redditors," submit content which is then voted upon by other members. The goal is to send well-regarded stories to the top of the site's main thread page. 
Pinterest is a social curation website for sharing and categorizing images found online. Pinterest requires brief descriptions but the main focus of the site is visual. Clicking on an image will take you to the original source, so, for example, if you click on a picture of a pair of shoes, you might be taken to a site where you can purchase them. An image of blueberry pancakes might take you to the recipe; a picture of a whimsical birdhouse might take you to the instructions.

\section{Social Audit:-}

The process of evaluating a firm's various operating procedures, code of conduct, and other factors to determine its effect on a society. The goal is to identify what, if any, actions of the firm have impacted the society in some way. A social audit may be initiated by a firm that is seeking to improve its cohesiveness or improve its image within the society. If the results are positive, they may be released to the public. For example, if a factory is believed to have a negative impact, the company may have a social audit conducted to identify actions that actually benefit the society.

\section{According to ministry of panchayati raj:-}

Social Audit - Social Audit process involves Auditing of various schemes by Social Auditor and Social Audit Facilitator and submission of audit report. SAMM aims to understand, measure, verify work under different schemes done by the Panchayat and further to improve social performance of respective Panchayats.

\section{How can social media play roles in social Audit:-}

While the use of social media and social business is growing as industries recognize their power, the risks of adoption should not be ignored. With its unique velocity, social media can damage a company's reputation in real time. Consider two scenarios where social media may have harmed an organization's brand and reputation:

A major U.S. food chain's social media account was hacked, resulting in a flurry of offensive posts, a rival company's profile picture being swapped for its own and an announcement that the company had even been sold to this rival. It took half a day for administrators to suspend the account, and a full day for the public relations team to issue an apology on the company's social media page.

A major automobile manufacturer invited the public to create advertisements for a new car. While the campaign was considered an overall success, hundreds of environmentalists created viral videos criticizing the auto company for contributing to global warming.

To help assess and reduce the risks of social media and social business, an important, but often overlooked, resource that organizations have is the internal audit (IA) function. "Internal auditors, with their training and experience to identify and assess risk, and their broad view of the organization, are in an ideal position to advise their organizations on how to manage risks appropriately," says Michael Juergens, a principal at Deloitte \& Touche LLP.

"Leading risk management practices for social media are still in their early stages and have evolved, to a large degree, reactively," Mr. Juergens adds. "What's more, many organizations have only fragmented views of their social media infrastructure, hindering effective risk management. As organizations seek to capitalize on the opportunities presented by social media, internal audit can play a critical advisory role.

According to a 2012 survey of 192 U.S. executives conducted by Deloitte \& Touche LLP and Forbes Insights, social media was identified as the fourth-largest risk through 2015, on par with financial risk. This ranking derives from social media's capacity to accelerate to other risks, such as financial risk associated with disclosures in violation of Securities and Exchange Commission rules, for example. Other risks inherent to social media include information leaks, reputational damage to brand, non-compliance with regulatory requirements, third- party and governance risks.

In each of these areas, internal audit can help their organizations in understanding potential risks, developing business processes to help mitigate them, monitoring compliance with implemented processes and assessing implemented controls. 


\section{Bibliography:-}

1. John Pearce, Peter Raynard, and Simon Zadek New Economics Foundation, London (1996)" Social Auditing for Small Organizations: A Workbook for Trainers and Practitioners" page no-28-34

2. Kurian Thomas,(2003) Community Based Self-help Groups in Andhra Pradesh State of India, Centre for Good Governance; Working paper No: 12-2003

3. Kumar Somesh, (2002) Methods for community participation: A complete guide for practitioners; Page no 28-38

4. Kumar Mahesh \& Chorasia T., (2014) "Social Audit:- Use as a Toolkit" from Bharatiya Bhasha, Siksha, Sahitya evam Shodh online ISSN 2321-9726 Volume-5, Issue-1, Page No.- 72-78

5. Kumar Mahesh \& Chorasia T. , (2014) "MNREGA - A Perspective" from International Research Journal of Management Sociology \& Humanities online ISSN 2277-9809 Volume -4, Issue-3, Page No.-421-447

6. Kumar Mahesh \& Chorasia T., (2014) "Regulation for Enterprise Development and Regulatory Impact Assessment" from International Research Journal of Commerce Art \& Science ISSN 2319-9202 Volume -5, Issue-1, Page No.- 134-167

7. Government of India,(2005) “MNREGA Samkeesha” from website http://www.nrega.nic.in accessed on dated $01 / 04 / 2012$

8. Governer ", "2013) World Bank Report” from website http://www.worldbank.org/ accessed on dated 31/03/2013

9. 2011 article, Jan H. Kietzmann, Kristopher Hermkens, Ian P. McCarthy and Bruno S. Silvestre

10. https://en.wikipedia.org/wiki/Social_media.

11. http://whatis.techtarget.com/definition/social-media.

12. http://planningcommission.gov.in/reports/sereport/ser/stdy_sagspr.pdf

13. http://www.businessdictionary.com/definition/socialaudit.html\#ixzz3tGiyplTe

14. http://deloitte.wsj.com/riskandcompliance/2014/05/23/social-media-risks- create-an-expanded-role-forinternal-audit-2/.

15. www.cgg.gov.in/.../Social\%20Audit\%20Toolkit\%20Final.pdf

16. unpan1.un.org/intradoc/groups/public/documents/.../unpan023752.pdf 